\title{
TINJAUAN PENGOLAHAN AIR MINUM DI PDAM KABUPATEN KEBUMEN TAHUN 2017
}

\author{
Nurul Ralin Fauziah ${ }^{1)}$, Hari Rudijanto IW $^{2)}$ \\ Jurusan Kesehatan Lingkungan, Politeknik Kesehatan Kemenkes Semarang, \\ Jl.Raya Baturaden KM 12 Purwokerto, Indonesia
}

\begin{abstract}
Abstrak
PDAM Kabupaten Kebumen merupakan perusahaan milik pemerintah daerah yang bergerak dalam bidang penyediaan air bagi masyarakat untuk memperoleh air minum dengan jumlah yang cukup sesuai syarat kesehatan sehingga harus diolah dengan baik. Metode yang digunakan adalah deskriptif yang bertujuan memperoleh gambaran kondisi pengolahan air minum di PDAM Kabupaten Kebumen. Hasil penelitian menunjukkan sumber air baku berasal dari sungai, waduk dan mata air yang kemudian diolah dengan sistem pengolahan lengkap. Kuantitas air yang dihasilkan dengan kapasitas produksi 322,50 liter/detik mampu menghasilkan air per hari sebanyak 18.949,54 $\mathrm{m}^{3}$. Kualitas air menunjukkan air tidak berbau, tidak berasa, sisa khlor pada 28 sampel terdapat 5 sampel yang hasilnya $0 \mathrm{mg} / \mathrm{liter}$, sedangkan total coliform yaitu 0 MPN/100 ml Golongan Coliform. Unit operasi pengolahan yang belum memenuhi prosedur yaitu unit intake, koagulasi dan flokulasi. Simpulan dari penelitian ini adalah kualitas air parameter bakteriologis sudah memenuhi syarat, sedangkan parameter warna, kekeruhan, sisa khlor dan pH ada yang belum memenuhi syarat. Kuantitas air sudah mencukupi kebutuhan. Penilaian unit operasi pengolahan diambil dari hasil checklist bahwa unit prasedimentasi, sedimentasi, filtrasi, desinfeksi dan reservoir dalam kategori "Baik". Saran bagi PDAM agar meningkatkan pemeliharaan dan perawatan unit operasi secara berkala sehingga hasil yang diperoleh lebih optimal.
\end{abstract}

Kata kunci: pengolahan air minum; kesehatan lingkungan

\begin{abstract}
[The Observation of Drinking Water Treatment in PDAM Kebumen District Year 2017] PDAM Kebumen Distric is a local goverment company which engaged in the field water supply for the citizen to get enough good quality of drinking water so it shoud be processed properly. The method used in description to determine the condition of drinking water treatment in PDAM Kebumen District. The result of this observation showed the source of raw water that came from river, reservoir and water spring then processed with complete processing system. The water quantity which capacity produce 322,50 liter/second could supply water 18.949,54 $\mathrm{m}^{3}$ each day. The water quality shown that water didn't smell, tasted, and chlor rest on 28 samples get rid of 5 samples result $0 \mathrm{mg} /$ liter, while coliform total is 0 MPN/100 ml Coliform Class. Operating unit that not meet the procedure are intake unit, coagulation and floculaction. The conclusion of this observation is the bacteriologist water quality parameter is qualified, while color parameter, turbidity and chlor rest some of them not eligible yet. The water quantity sufficient need already. The assessment of operating unit was taken by checklist result which prasedimentation, sedimentation, filtration, disinfection and reservoir in "Good" category. Suggestion for PDAM to improve the maintenance and caring of the processing unit periodically so the result are more optimal.
\end{abstract}

Keywords: drinking water treatment; environmenthal health

\section{Pendahuluan}

Pembangunan kesehatan bertujuan untuk meningkatkan kesadaran, kemauan dan kemampuan

${ }^{1)}$ E-mail: nurulralin@gmail.com

${ }^{2)}$ E-mail: hariokey2000@yahoo.com hidup sehat bagi setiap orang agar terwujudnya derajat kesehatan masyarakat yang setinggi-tingginya sebagai investasi bagi pembangunan sumber daya manusia yang produktif secara sosial dan ekonomis. Untuk mewujudkan derajat kesehatan yang optimal salah satu 
upaya yang perlu dilakukan adalah pemenuhan kebutuhan air minum yang sehat (UU RI. No 36 Tahun 2009, h.3).

Kesehatan lingkungan adalah upaya pencegahan penyakit dan atau gangguan kesehatan dari faktor risiko lingkungan untuk mewujudkan kualitas lingkungan yang sehat baik dari aspek fisik, kimia, biologi, maupun sosial. Standar Baku Mutu Kesehatan Lingkungan dan Persyaratan Kesehatan ditetapkan pada media lingkungan yang salah satunya yaitu air (PP No 66 Tahun 2014, h.1).

Air merupakan kebutuhan yang sangat vital bagi kehidupan manusia. Karena itu jika kebutuhan akan air tersebut belum tercukupi maka dapat memberikan dampak yang besar terhadap kerawanan kesehatan maupun sosial. Air dibutuhkan sepanjang masa baik langsung maupun tidak langsung, sehingga air harus memenuhi syarat dari segi kuantitas dan kualitas. Menurut Permenkes RI No. 492/Menkes/Per/IV/2010 tentang Persyaratan Kualitas Air Minum bahwa air minum aman bagi kesehatan apabila memenuhi persyaratan fisika, bakteriologi, kimiawi dan radioaktif yang dimuat dalam parameter wajib dan parameter tambahan.

Parameter kualitas air minum yang berhubungan langsung dengan kesehatan menurut Permenkes tersebut yaitu E.Coli dan total bakteri Coliform, sedangkan yang berhubungan dengan kimia anorganik yaitu arsen, fluorida, total kromium, kadmium, nitrit, nitrat, sianida, dan selenium. Parameter yang tidak langsung berhubungan dengan kesehatan yaitu parameter fisik yang meliputi bau, warna, TDS (Total zat padat terlarut), kekeruhan, rasa, dan suhu. Parameter kimiawi yang meliputi aluminium, besi, kesadahan, khlorida, mangan, $\mathrm{pH}$, seng, sulfat, tembaga, dan ammonia.

Kualitas air yang tidak memenuhi kualitas air minum dapat mengganggu kesehatan masyarakat karena air dapat sebagai water borne diseases yaitu penyakit yang ditularkan melalui air yang tidak sehat. Penyakit yang dapat ditularkan melalui media air yang tidak sehat diantaranya yang disebabkan oleh parasit seperti kecacingan, penyakit yang disebabkan oleh bakteri seperti typus, kolera, disentri, diare dan penyakit yang disebabkan oleh virus seperti hepatitis, polio.

Perusahaan Daerah Air Minum (PDAM) mengolah air yang diambil dari waduk, mata air, maupun sungai dan banyak masyarakat selama ini mengkonsumsi air minum yang diolah oleh PDAM. Seiring dengan semakin majunya teknologi maka diiringi dengan semakin sibuknya aktivitas manusia maka masyarakat lebih cenderung memilih cara yang praktis dengan biaya yang relatif lebih murah dalam memenuhi kebutuhan air minum. Salah satu pemenuhan kebutuhan air minum yang menjadi alternatif dengan menggunakan air minum yang diolah oleh PDAM.
PDAM adalah perusahaan milik pemerintah daerah yang bergerak dalam bidang penyediaan air bagi masyarakat untuk memperoleh air minum dengan jumlah yang cukup serta memenuhi syarat-syarat kesehatan. PDAM Kabupaten Kebumen untuk melayani kebutuhan air minum menggunakan sumber air baku yang berada di waduk Sempor, mata air di Desa Sikayu, dan sungai Luk Ulo, kemudian sumber pengolahan air minum berada di Sempor, Pejagoan, Alian dan Kutowinangun.

PDAM Kabupaten Kebumen sudah melakukan pemeriksaan kualitas air oleh Balai Besar Teknik Lingkungan dan Pengendalian Penyakit Yogyakarta serta Laboratorium Kesehatan Kebumen. Pemeriksaan dilakukan pada tanggal 10 November 2016 dan hasilnya ada yang belum memenuhi persyaratan kesehatan. Parameter yang diperiksa yaitu parameter bakteriologi, parameter fisika, dan parameter kimia. Parameter yang belum memenuhi persyaratan kesehatan yaitu parameter fisika seperti bau (berbau kaporit), jumlah zat padat terlarut (TDS), dan kekeruhan, kemudian untuk parameter kimia yang belum memenuhi persyaratan kesehatan yaitu kesadahan sebagai $\mathrm{CaCO}_{3}$ dan detergen.

Proses pengolahan yang digunakan meliputi intake, prasedimentasi, koagulasi, flokulasi, sedimentasi, filtrasi, desinfeksi, dan distribusi ke pelanggan. Air baku yang sulit untuk diproses yaitu limbah dari penduduk seperti detergen, penebangan kayu yang banyak getahnya, serta kolam perikanan yang airnya bau dan keruh, sehingga hasil akhir dari pemeriksaan belum memenuhi syarat. Hal tersebut dapat terjadi pencemaran yang dapat menimbulkan gangguan kesehatan bagi konsumen, antara lain penyakit yang disebabkan oleh kualitas air yang kurang bersih dan sanitasi sarana air minum yang kurang baik.

Rumusan masalah yang akan diteliti adalah bagaimanakah gambaran pengolahan air minum di PDAM Kabupaten Kebumen.

Tujuan umum dari penelitian ini adalah mengetahui kondisi pengolahan air minum di PDAM Kabupaten Kebumen, sedangkan tujuan khusus yaitu mendiskripsikan proses pengolahan air minum yang dilaksanakan, menilai unit operasi pengolahan air minum, kualitas dan kuantitas air minum yang dihasilkan serta mengetahui wilayah pendistribusian dari PDAM Kabupaten Kebumen.

\section{Bahan dan Metode}

Penelitian ini dilaksanakan di PDAM Kabupaten Kebumen, Jalan Aroengbinang Nomor 12, Kebumen Jawa Tengah. Subyek dalam penelitian ini adalah sarana pengolahan air minum yang ada di PDAM Kabupaten Kebumen.

Jenis penelitian yang digunakan adalah deskriptif yang bertujuan memperoleh gambaran tentang kondisi 
sarana pengolahan air minum di PDAM Kabupaten Kebumen.

Analisis yang dipakai dalam penelitian ini adalah analisis tabel yang berisikan data hasil pengukuran dan pengamatan dibandingkan dengan teori-teori yang relevan dan standar persyaratan yang berlaku yaitu menurut Permenkes RI No. 492/Menkes/Per/IV/2010 tentang Persyaratan Kualitas Air Minum.

Sumber data terdiri dari sumber data primer yang berasal dari kegiatan pengamatan terhadap keadaan sanitasi sarana air minum dan wawancara dengan petugas bagian pengolahan air minum yang ada di PDAM Kabupaten Kebumen dengan menggunakan checklist dan kuesioner, serta sumber data sekunder meliputi : arsip kantor PDAM Kabupaten Kebumen untuk memperoleh data wilayah pendistribusian, jumlah pendistribusian per hari, jumlah pelanggan, sarana dan prasarana di PDAM Kabupaten Kebumen, hasil pemeriksaan kualitas air minum dari Balai Besar Teknik Lingkungan dan Pengendalian Penyakit Yogyakarta serta Laboratorium Kesehatan Daerah Kebumen.

\section{Hasil dan Pembahasan}

PDAM Tirta Bumi Sentosa Kabupaten Kebumen semula berkedudukan di Gombong yang merupakan instalasi sistem air bersih peninggalan Belanda (beroperasi sejak tahun 1916) dan dalam Pemerintah Republik Indonesia sistem air bersih ini langsung dikelola oleh Pemda TK II Kebumen. Perkembangan lebih lanjut sistem air bersih di Gombong ini dijadikan BUMD yang didirikan dengan Perda Kabupaten Dati II Kebumen Nomor 4 Tahun 1978.

Keberadaan PDAM Kabupaten Kebumen di Gombong, berdasarkan Surat Keputusan Menteri Pekerjaan Umum Nomor: 42/KPTS/1987 tanggal 2 Februari 1987, dibentuk Badan Pengelola Air Minum (BPAM) Kabupaten Kebumen yang bertugas mengelola proyek sistem air bersih untuk Kabupaten Kebumen. Berdasarkan Perda Kabupaten Dati II Kebumen Nomor 8 Tahun 1993 dibentuklah PDAM Kabupaten Kebumen di Gombong dan BPAM Kabupaten Kebumen, diubah berdasarkan Perda Kabupaten Kebumen Nomor 2 Tahun 2002 dan terakhir diubah berdasarkan Perda Kabupaten Kebumen Nomor 13 Tahun 2010.

Wilayah pelayanan PDAM Tirta Bumi Sentosa Kabupaten Kebumen meliputi 16 kecamatan antara lain : Kecamatan Kebumen, Pejagoan, Alian, Ayah, Rowokele, Prembun, Kutowinangun, Buayan, Kuwarasan, Karanganyar, Sruweng, Karanggayam, Gombong, Sempor, Adimulyo dan Buayan dengan jumlah pelanggan sebanyak 146.464 jiwa.

Secara geografi Kabupaten Kebumen terletak di pesisir selatan Jawa Tengah. Apabila dilihat dari kemiringan tanah pada bagian selatan Kabupaten Kebumen merupakan dataran rendah, sedangkan pada bagian utara berupa pegunungan yang merupakan bagian dari rangkaian Pegunungan Serayu. Di selatan daerah Gombong terdapat rangkaian pegunungan kapur, yang membujur hingga pantai selatan dengan ketinggian berkisar antara 0-997,5 $\mathrm{m}$ di atas permukaan laut. Daerah ini terdapat sejumlah gua dengan stalagtit dan stalagmit. Jumlah pegawai yaitu 105 orang yang terdiri dari 1 orang direktur, 102 orang pegawai tetap dan 2 orang tenaga kontrak.

Struktur organisasi yang terdapat di PDAM Tirta Bumi Sentosa sudah tersusun secara baik sesuai dengan tugas dan wewenang yang sudah ditentukan. PDAM dipimpin oleh seorang direktur yang bertanggungjawab kepada bupati melalui badan pengawas. Kepengurusan tata usaha PDAM Tirta Bumi Sentosa ditetapkan berdasarkan Surat Keputusan Bupati Kebumen Nomor 2 Tahun 2002 tanggal 2 April 2002 tentang Pembentukan Susunan Organisasi dan Tata Kerja Perusahaan Daerah BPR, Bank Pasar, PDAM dan Perusda Apotik Luk Ulo.

\section{a. Sumber air baku yang digunakan di PDAM Tirta}

\section{Bumi Sentosa}

Sumber air baku yang digunakan untuk sarana pengolahan air minum berasal dari beberapa sungai, mata air dan waduk yang ada di Kabupaten Kebumen, antara lain sebagai berikut :

Tabel 1. Sumber Air Baku dan Kapasitas Produksi di PDAM Tirta Bumi Sentosa Tahun 2017

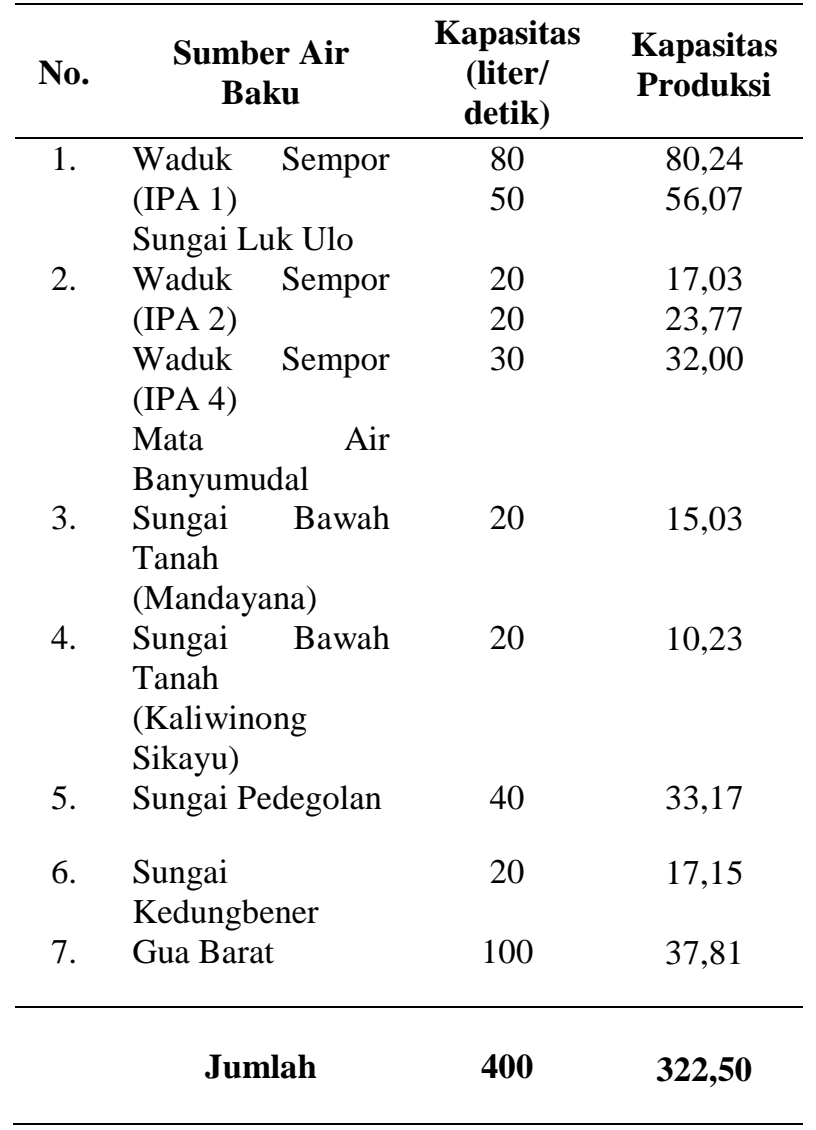


Jam operasi produksi dan distribusi di PDAM untuk masing-masing sumber air dapat dilihat pada Tabel 2. sebagai berikut :

Tabel 2. Jam Operasi Produksi dan Distribusi PDAM Tirta Bumi Sentosa Tahun 2017

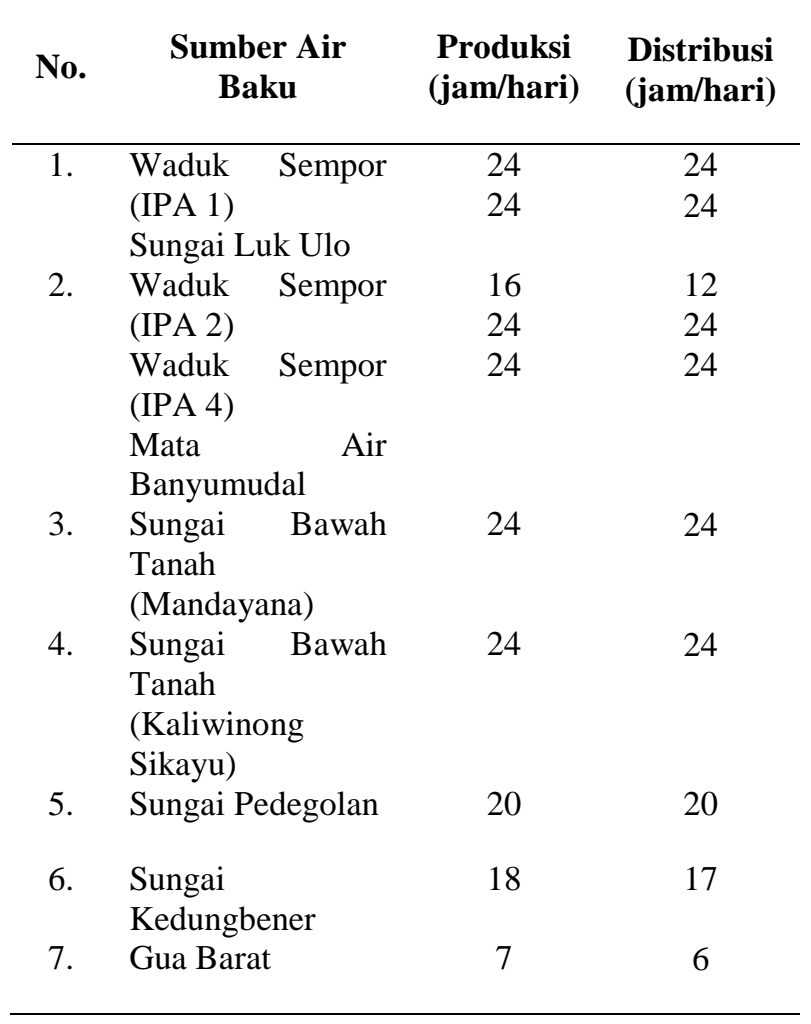

Adapun pembagian jam kerja untuk 3 shift di masing-masing unit instalasi pengolahan air yaitu :

Tabel 3. Pembagian Jam Kerja untuk Hari SeninMinggu di PDAM Tirta Bumi Sentosa Tahun 2017

\begin{tabular}{crc} 
Shift & Jam Kerja & Istirahat \\
\hline I & $07.00-15.00$ & 1 jam \\
II & $15.00-22.00$ & 1 jam \\
III & $22.00-07.00$ & 1 jam \\
\hline
\end{tabular}

\section{b. Proses pengolahan air minum di PDAM Tirta Bumi Sentosa}

Instalasi pengolahan air minum yang terdapat di PDAM Tirta Bumi Sentosa Kabupaten Kebumen merupakan jenis pengolahan air lengkap. Dapat dilihat dengan bagan sebagai berikut :

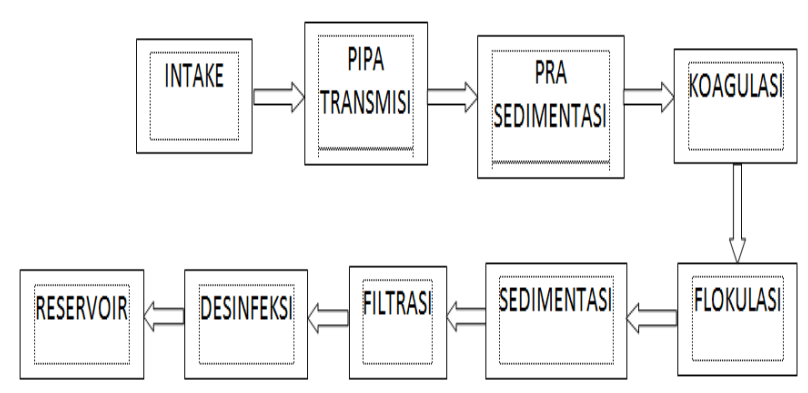

Gambar 1. Bagan Proses Pengolahan Air Minum di PDAM Tirta Bumi Sentosa Kabupaten Kebumen

1) Intake

Intake adalah bangunan yang berfungsi sebagai penangkap air baku yang akan diolah secara lengkap di instalasi pengolahan air PDAM. Bangunan ini berbentuk persegi dengan ukuran panjang $4 \mathrm{~m}$, lebar $4 \mathrm{~m}$ dan kedalaman $6 \mathrm{~m}$. Masing-masing air baku yang berasal dari sungai dan waduk dialirkan dari intake ke bak prasedimentasi menggunakan pipa Galvanize Iron (GI). Bangunan ini dilengkapi dengan screening yang berfungsi sebagai penangkap benda terapung dan melayang. Screening ini terbuat dari bahan besi yang berdiameter $52 \mathrm{~mm}$ dengan jarak antar batang $25 \mathrm{~mm}$ dan diletakkan di mulut intake. Intake dibangun di lokasi yang menjamin tersedianya kualitas dan kuantitas air yang baik.

PDAM Tirta Bumi Sentosa menggunakan intake saluran untuk sumber air yang berasal dari sungai dan dilengkapi dengan screening yang berfungsi sebagai penangkap benda terapung, sedangkan untuk sumber air yang berasal dari waduk dan mata air menggunakan intake gate. Bangunan intake sudah memenuhi persyaratan karena sudah mampu menampung air sesuai banyaknya air yang akan diolah. Bangunan ini berlokasi di daerah yang menjamin tersedianya kualitas air yaitu di daerah yang belum terdapat buangan limbah industri.

Tujuan screening diletakkan di depan mulut intake adalah agar tidak ada sampah yang masuk kedalam intake, walupun intake sudah dilengkapi dengan penyaring sampah maka fungsi lain dari screening dapat juga agar meringankan fungsi penyaring sampah yang terdapat dimulut intake.

Pembersihan screening secara manual merupakan pembersihan yang menggunakan tenaga manusia dengan cara mengambil (menggaruk) benda yang tersangkut di screen dibawa ke atas atau disingkirkan dari screen.

2) Pipa Transmisi Air Baku

Pipa ini terbuat dari bahan yang kuat, pipa yang digunakan adalah pipa Galvanize Iron (GI). Pipa masih dalam kondisi yang baik dan terlindung dengan membenam pipa di dalam tanah. Diameter pipa transmisi untuk Unit Pejagoan yaitu 14 inch, diameter pipa transmisi untuk Unit Ungaran yaitu 8 inch, diameter pipa transmisi untuk Unit Alian yaitu 10 inch, diameter pipa transmisi untuk Unit Sempor yaitu 16 
inch, diameter pipa transmisi untuk Unit Banyumudal yaitu 12 inch, diameter pipa transmisi untuk Unit Kaliwinong yaitu 14 inch, dan diameter pipa transmisi untuk Unit Mandayana yaitu 6 inch.

Pipa transmisi air baku berfungsi sebagai pipa pembawa aliran air baku dari intake ke bak prasedimentasi dengan beda tinggi \pm 20 meter (ketinggian prasedimentasi $=20$ meter di atas bangunan intake).

3) Prasedimentasi

Bangunan prasedimentasi mempunyai fungsi mengendapkan partikel-partikel kasar yang dapat mengendap sendiri dengan sistem gravitasi tanpa bantuan bahan kimia dan dalam keadaaan tenang. Bangunan prasedimentasi di PDAM Tirta Bumi Sentosa berbentuk persegi panjang dengan ukuran panjang 9,2 $\mathrm{m}$, lebar $6,5 \mathrm{~m}$ dan kedalaman $6 \mathrm{~m}$ yang terbuat dari beton bertulang dan masih dalam keadaan baik.

Bangunan ini terdiri dari 3 bagian utama yaitu zona inlet merupakan zona air masuk ke bangunan prasedimentasi. Bak pertama ini dibuat merata pada lebar bak. Bagian yang kedua merupakan zona lumpur berbentuk limas dengan tujuan agar lumpur mudah mengendap tanpa tambahan zat koagulan. Bagian yang ketiga adalah zona outlet merupakan tempat keluarnya air yang terdapat di permukaan dari prasedimentasi untuk masuk ke bak koagulasi.

Bentuk bak persegi panjang memiliki kinerja lebih baik dari bentuk bak bujur sangkar karena memiliki kemampuan untuk meredam terjadinya pusaran air yang akan menurunkan efisiensi pengendapan. Aliran air pada bak prasedimentasi mengalir secara laminar agar kandungan lumpur yang terdapat pada air baku dapat mengendap dengan sendirinya tanpa bantuan zat koagulan. Aliran laminar dapat mengendapkan flok secara gravitasi dengan waktu pengendapan berkisar antara 2-3 jam. Zona lumpur berbentuk limas agar lumpur mudah untuk mengendap sehingga meringankan proses selanjutnya. Zona outlet diletakkan dipermukaan dan dilengkapi dengan weir sebelum dialirkan ke proses selanjutnya. Hal itu untuk menjaga agar tidak terjadi penggerusan terhadap lumpur yang sudah mengendap.

4) Koagulasi

Prinsip koagulasi yaitu distabilisasi agragesi dan pengikatan koloid secara bersama-sama, sedangkan proses yang menyangkut pembentukan flok-flok yang mengabsorbsi dan menangkap partikel koloid dalam air sehingga terbentuk flok yang lebih besar, dan akan lebih mudah diendapkan di bak sedimentasi.

Pada instalasi pengolahan di PDAM Tirta Bumi Sentosa proses koagulasi yang digunakan adalah dengan menggunakan sistem pengaduk cepat. Bangunan unit ini berukuran dengan panjang 3,3 m, lebar 2,3 m dan kedalaman $6 \mathrm{~m}$. Bangunan koagulasi terdiri dari 2 bagian, yang pertama yaitu bak untuk menampung aliran air baku dari prasedimentasi ke bak koagulasi dan yang kedua bak untuk menampung aliran air dari bak koagulasi menuju bak flokulasi. Kondisi bagunan masih dalam keadaan baik.

Pada proses ini larutan yang digunakan adalah PAC (Poly Alumunium Chloride), karena PAC mempunyai kelebihan dapat bekerja ditingkatan $\mathrm{pH}$ yang lebih luas dengan demikian tidak diperlukan mengoreksi $\mathrm{pH}$, PAC tidak akan menjadi keruh jika pemakaian berlebihan.

Penggunaan PAC di PDAM Tirta Bumi Sentosa dengan dosis $8 \mathrm{ppm}$ berhasil menurunkan kekeruhan dari 125 NTU menjadi 1 NTU. Sistem pembubuhan larutan koagulan dilakukan dengan pengaturan bukaan dosering. Pembubuhan dosering PAC diteteskan secara gravitasi pada bak koagulasi dan pada bak ini dilengkapi dengan alat ukur debit. Alat ukur debit ini digunakan untuk memperkirakan debit pengolahan air baku. Pada awal operasi harus menentukan debit air baku yang akan diolah. Dosis PAC ditentukan sesuai dengan hasil jartest sebelumnya, begitupun bila kekeruhan air baku berubah.

Pemeliharaan dilakukan setiap hari yaitu melakukan pengontrolan terutama untuk pemeriksaan peralatan pembubuhan PAC agar nilai efisiensi proses pengolahan tercapai dengan seoptimal mungkin, maka operator harus selalu memantau kualitas air baku yang akan diolah dari parameter warna, kekeruhan, dan $\mathrm{pH}$ sesuai petunjuk operasional.

5) Flokulasi

Setelah proses koagulasi dilanjutkan proses flokulasi. Bak flokulasi terbuat dari bahan cor semen yang berbentuk lingkaran dengan dasar kerucut sebagai tempat penampung flok hasil koagulasi dan bangunan masih dalam keadaan baik. Pada bak dibuat arah aliran air berkelak-kelok dengan masing-masing bak berdiameter $1,4 \mathrm{~m}$ dan kedalamannya $6 \mathrm{~m}$. Untuk penghubung aliran air antara bak satu dengan bak yang lain dibuat lubang dengan arah aliran air berbelok. Setiap ujung dinding penyekat dibuat lubang agar air dapat mengalir secara berbelok. Bak flokulasi mudah dibersihkan tetapi terkadang masih terdapat adanya lumut yang menempel pada bak tersebut.

Menurut Asmadi dkk (2011, h.57), flokulasi adalah suatu proses aglomerasi atau pengumpulan partikel-partikel terdestabilisasi menjadi flok dengan ukuran yang memungkinkan dapat dipisahkan oleh sedimentasi dan filtrasi. Unit flokulasi pengolahan air di PDAM Tirta Bumi Sentosa terdiri dari 8 buah bak dan dibuat secara turbulen dengan sistem horizontal yang setiap baknya diberi aliran berkelok-kelok. Tujuannya adalah agar inti flok yang terbentuk melalui proses koagulasi dapat menempel satu sama lain dan kemudian terjadi flok-flok yang berukuran besar dan berat sehingga dapat diendapkan melalui proses sedimentasi. Pada setiap ujung dindingnya penyekat dibuat lubang agar dapat mengalir turbulen. 


\section{6) Sedimentasi}

Unit sedimentasi masih dalam keadaan baik. Bangunan terbuat dari semen cor mudah dibersihkan dan dilengkapi dengan bangunan penguras lumpur. Pada zona inlet terdapat pintu bukaan atau lubang dengan diameter 10 inch yang akan mengalirkan air dari bak flokulasi masuk ke bak sedimentasi, kemudian diendapkan dan air masuk ke zona outlet yang langsung masuk ke bak filtrasi. Pada kedalaman $1 \mathrm{~m}$ terdapat plate settler yang dipasang berderet dengan kemiringan tertentu yang bertujuan untuk meningkatkan efisiensi dan memperluas bidang pengendapan sehingga proses fisika dari sedimentasi dapat berlangsung lebih effektif. Kemudian di bagian bawahnya terdapat ruang miring sehingga tampak samping membentuk jajaran genjang dengan kedalaman $2 \mathrm{~m}$, selanjutnya bak kembali persegi panjang dengan kedalaman $2 \mathrm{~m}$.

Bangunan sedimentasi yang berada di PDAM Tirta Bumi Sentosa ditujukan untuk pengendapan flokflok yang telah terbentuk pada proses flokulasi. Dengan adanya plate settler aliran akan menjadi tenang. Flokflok yang masih terbawa oleh aliran air yang akan membentuk pada plate-plate dan bergabung dengan flok lain, lama kelamaan flok-flok tersebut menjadi berat sehingga dengan mudah dapat mengendap. Endapan flok ditampung di bak lumpur yang terdapat di bawah bangunan, dan akan dikuras apabila sudah melewati batas bak lumpur atau flok sudah mulai mengapung.

7) Filtrasi

Pada bangunan filtrasi terdapat 6 buah bak filtrasi. Setiap bak memiliki sebuah talang masukan dan talang pembuangan air pencuci media filter. Masingmasing bak masih dalam keadaan baik. Tinggi bak total adalah $6 \mathrm{~m}$, dengan tinggi air maksimum 4,5 m dan tinggi media pasir $1,2 \mathrm{~m}$. Ukuran media penyaringan pasir silika yaitu berdiameter $0,4-0,8 \mathrm{~mm}$. Pada saat proses penyaringan berlangsung, air mengalir (meresap) secara gravitasi melalui media penyaringan dan akan masuk ke pipa manifold melalui lubang pipa lateral. Partikel koloid yang tidak bisa diendapkan oleh sedimentasi akan ditahan oleh media penyaringan (pasir silika) dan air yang sudah melewati media penyaring kemudian dialirkan ke pipa dan ditampung ke bak penampung (reservoir) untuk dilakukan proses desinfeksi.

Unit fitrasi dibuat 6 buah bak karena apabila bak yang 1 sedang dilakukan pencucian maka proses filtrasi masih tetap bisa berjalan. Sistem filltrasi adalah sistem saringan pasir yang memiliki kemampuan penyaringan rata-rata $25 \mathrm{~m}^{3} / \mathrm{m}^{2} / \mathrm{jam}$. Tinggi lapisan air yang berada di atas media penyaring (supernatant) dibuat sedemikian rupa agar dapat menghasilkan tekanan (head) sehingga dapat mendorong air mengalir melalui media pasir. Di samping itu juga berfungsi agar dapat memberikan waktu tinggal air yang akan diolah di dalam media pasir sesuai dengan kriteria disain.

\section{8) Desinfeksi}

Desinfektan yang digunakan di PDAM Tirta Bumi Sentosa yaitu gas khlor. Pembubuhan larutan desinfektan yaitu $1 \mathrm{ppm}\left(1 \mathrm{gr} / \mathrm{m}^{3}\right)$ yang artinya adalah 1 gr khlorin untuk $1 \mathrm{~m}^{3}$ air. Pembubuhan dilakukan dengan perhitungan yang sesuai dengan standar yang sudah ditetapkan. Tujuan desinfeksi untuk membunuh bakteri pathogen yang merugikan kehidupan manusia. Selain itu untuk memberikan jaminan bahwa air dapat digunakan secara aman.

Sistem pengaliran menggunakan sistem gravitasi dengan dosis yang digunakan misal untuk debit 50 liter/detik yang menghasilkan $180 \mathrm{~m}^{3} / \mathrm{jam}$ dengan pembubuhan sebanyak $1 \mathrm{ppm} \quad\left(\begin{array}{ll}\left.1 \mathrm{gr} / \mathrm{m}^{3}\right) & \text { maka }\end{array}\right.$ dibutuhkan gas khlor sebesar 0,18 $\mathrm{kg} / \mathrm{jam}$ atau 4,32 $\mathrm{kg} /$ hari dan pembubuhan desinfektan sudah sesuai SOP. Apabila dosis yang digunakan melebihi prosedur yang telah ditetapkan maka dapat berdampak pada kesehatan manusia.

\section{9) Reservoir}

Air yang telah selesai dilakukan pengolahan kemudian ditampung di bak reservoir. Bak reservoir dibagi menjadi 2 bagian dengan tujuan jika pada saat proses pencucian maka salah satu bak dimatikan dan bak yang satunya masih tetap bisa mendistribusikan ke pelanggan. Masing-masing bak masih dalam keadaan baik.

Bak reservoir berbentuk persegi dengan ukuran setiap unit berbeda-beda, namun dengan tinggi volume air maksimum 5 m. Unit Pejagoan memiliki ukuran bak $1200 \mathrm{~m}^{3}$, Unit Ungaran memiliki ukuran bak $400 \mathrm{~m}^{3}$, Unit Alian memiliki ukuran bak $200 \mathrm{~m}^{3}$, Unit Sempor memiliki ukuran bak $2000 \mathrm{~m}^{3}$, Unit Banyumudal memiliki ukuran bak $500 \mathrm{~m}^{3}$, Unit Buayan memiliki ukuran bak $200 \mathrm{~m}^{3}$, dan Unit Ayah memiliki ukuran bak $200 \mathrm{~m}^{3}$.

Pada unit ini dilakukan pemeriksaan kualitas fisik, kimia, dan bakteriologis. Untuk pemeriksaan fisik dan pemeriksaan kimia dilakukan setiap 3 bulan sekali yang kemudian dikirim ke Balai Besar Teknik Kesehatan Lingkungan dan Pengendalian Penyakit di Yogyakarta, serta untuk pemeriksaan bakteriologis dilakukan setiap sebulan sekali di Laboratorium Daerah Kebumen.

\section{c. Sistem jaringan perpipaan di PDAM Tirta Bumi Sentosa Kabupaten Kebumen}

Jaringan perpipaan PDAM Tirta Bumi Sentosa yang berada di beberapa lokasi berdiameter pipa transmisi mulai dari 4 inch sampai 16 inch, sedangkan untuk pipa distribusi mulai dari 11/2 inch sampai 4 inch. 
Tabel 4. Diameter Pipa Transmisi dan Distribusi PDAM Tirta Bumi Sentosa Kabupaten Kebumen Tahun 2017

\begin{tabular}{|c|c|c|c|}
\hline No. & $\begin{array}{c}\text { Sumber Air } \\
\text { Baku }\end{array}$ & $\begin{array}{l}\text { Diameter } \\
\text { Pipa } \\
\text { Transmisi }\end{array}$ & $\begin{array}{l}\text { Diameter } \\
\text { Pipa } \\
\text { Distribusi }\end{array}$ \\
\hline 1. & $\begin{array}{l}\text { Waduk Sempor } \\
\text { (IPA 1) } \\
\text { Sungai Luk Ulo }\end{array}$ & $\begin{array}{c}\text { 10, 12, dan } \\
16 \text { inch } \\
14 \text { inch }\end{array}$ & $\begin{array}{l}2,3,4,6,8 \\
\text { dan } 10 \text { inch } \\
2,3,4,6,8 \\
\text { dan } 10 \text { inch }\end{array}$ \\
\hline 2. & $\begin{array}{l}\text { Waduk Sempor } \\
\text { (IPA 2) } \\
\text { Waduk Sempor } \\
\text { (IPA 4) } \\
\text { Mata Air } \\
\text { Banyumudal }\end{array}$ & $\begin{array}{c}10 \text { inch } \\
10 \text { inch } \\
7 \text { dan } 12 \\
\text { inch }\end{array}$ & $\begin{array}{c}\text { 2, 3, 4, 6, } 8 \\
\text { dan } 10 \text { inch } \\
2,3,4,6,8 \\
\text { dan } 10 \text { inch } \\
\text { 2, 3, 4, } 6 \text { dan } \\
8 \text { inch }\end{array}$ \\
\hline 3. & $\begin{array}{l}\text { Sungai Bawah } \\
\text { Tanah } \\
\text { (Mandayana) }\end{array}$ & 6 inch & $\begin{array}{l}\text { 2, } 3 \text { dan } 4 \\
\text { inch }\end{array}$ \\
\hline 4. & $\begin{array}{l}\text { Sungai Bawah } \\
\text { Tanah } \\
\text { (Kaliwinong } \\
\text { Sikayu) }\end{array}$ & 14 inch & $\begin{array}{c}\text { 2, 3, } 4 \text { dan } 6 \\
\text { inch }\end{array}$ \\
\hline 5. & $\begin{array}{l}\text { Sungai } \\
\text { Pedegolan }\end{array}$ & 8 inch & $\begin{array}{c}\text { 2, 3, } 4 \text { dan } 6 \\
\text { inch }\end{array}$ \\
\hline 6. & $\begin{array}{l}\text { Sungai } \\
\text { Kedungbener }\end{array}$ & 10 inch & $\begin{array}{c}3,4,6,8 \text { dan } \\
10 \text { inch }\end{array}$ \\
\hline 7. & $\begin{array}{l}\text { Gua } \\
\text { Buayan }\end{array}$ & $\begin{array}{c}10 \text { dan } 12 \\
\text { inch }\end{array}$ & $\begin{array}{c}\text { 3, 4, 6, } 8 \text { dan } \\
10 \text { inch }\end{array}$ \\
\hline
\end{tabular}

Berdasarkan hasil pengamatan yang telah dilakukan, pemeliharaan perpipaan tergolong baik. Hal ini dapat dilihat dari jumlah perpipaan yang mengalami kebocoran hanya sedikit. Pemeliharaan bangunan unit pengolahan juga relatif baik, karena meskipun berada ditempat yang lembab namun tidak terlalu banyak lumut, bangunan tampak kokoh.

Kondisi perpiapan di jaringan distribusi PDAM Tirta Bumi Sentosa sebagian besar sudah menggunakan pipa Galvanize Iron (GI) dan pipa PVC. Namun untuk pipa GI terkadang mengalami kebocoran karena pipa sudah dipakai sejak lama.

Sistem distribusi air yang digunakan di PDAM Kabupaten Kebumen menggunakan sistem gravitasi. Sistem gravitasi adalah sistem yang paling menguntungkan, karena sistem ini mengikuti sifat air mengalir dari tempat yang tinggi ketempat yang lebih rendah. Adapula sistem distribusi yang menggunakan pompa listrik yang berarti akan menambah biaya operasional dan juga pemeliharaannya dibandingkan dengan sistem gravitasi.
Beberapa sumber air baku yang ada kemudian diolah di masing-masing Unit IPA dan oleh PDAM dibagi menjadi 7 daerah pelayanan. Pelayanan PDAM saat ini mencapai 23.972 sambungan rumah yaitu $31,60 \%$ dari jumlah sambungan rumah total di Kabupaten Kebumen. Daerah pelayanan diantaranya adalah Kota Kebumen, IKK Ayah, IKK Kutowinangun, Buayan, IKK Karanganyar, IKK Gombong, dan IKK Alian.

Berdasarkan beberapa sumber air baku yang ada kemudian diolah di unit-unit Instalasi Pengolahan Air (IPA) dan oleh PDAM dibagi menjadi 7 daerah pelayanan. Pelayanan PDAM saat ini mencapai 23.972 sambungan rumah yaitu 31,60\% dari jumlah sambungan rumah total di Kabupaten Kebumen.

\section{d. Hasil penilaian unit proses pengolahan air minum} 1) Intake

Berdasarkan pengamatan yang telah dilakukan, didapatkan hasil bahwa unit intake termasuk dalam kategori penilaian "Tidak Baik" karena masih terdapat item yang belum terpenuhi. Hal ini dikarenakan pada PDAM Tirta Bumi Sentosa saat pembersihan kisi-kisi pada screening hanya dilakukan secara manual.

Jenis pembersihan lainnya yang biasa digunakan adalah pembersihan secara mekanik. Pembersihan ini mengandalkan tenaga mekanis, yaitu alat pengambil (penggaruk) benda yang tersangkut di screen yang berjalan terus-menerus dengan digerakkan oleh motor. Sebaiknya dalam pembersihan kisi-kisi pada screening dilakukan secara mekanik. Pembersihan secara mekanik dapat lebih efisien dan hasilnya lebih optimal serta dapat menghemat tenaga pekerja.

2) Prasedimentasi

Menurut Totok Sutrisno (2006, h.53) bangunan prasedimentasi berfungsi untuk mengendapkan partikel padat dari air sungai dengan gaya gravitasi dan waktu pengendapan berkisar antara 2-3 jam. Aliran air harus dijaga supaya aliran air pada unit ini laminar (tenang), dengan demikian pengendapan secara gravitasi tidak terganggu. Hal ini dapat dilakukan dengan mengatur pintu air masuk dan pintu air keluar pada unit ini. Berdasarkan pengamatan yang telah dilakukan, didapatkan hasil bahwa unit prasedimentasi termasuk dalam kategori penilaian "Baik" karena semua item yang ada telah terpenuhi. Pada bak prasedimentasi dilengkapi dengan pipa penguras dan kantong lumpur. Hasil pengendapan pada unit ini yaitu terbentuknya lumpur endapan pada dasar bak. Pengurasan bak prasedimentasi biasanya dilakukan 3-4 bulan sekali.

3) Koagulasi

Berdasarkan pengamatan yang telah dilakukan, didapatkan hasil bahwa unit koagulasi termasuk dalam kategori penilaian "Tidak Baik" karena pada proses ini, koagulan sebelum dibubuhkan tidak dilakukan jar-test terlebih dahulu. Sebaiknya sebelum dilakukan 
pembubuhan harus ditentukan dosis koagulan terlebih dahulu dengan menggunakan jar-test.

4) Flokulasi

Berdasarkan pengamatan yang telah dilakukan, didapatkan hasil bahwa unit flokulasi termasuk dalam kategori penilaian "Tidak Baik" karena pada unit ini tidak menggunakan bahan Soda Ash, tetapi hanya PAC pada proses koagulasi. Biasanya pada unit ini dilakukan pembubuhanmdengan cara basah atau kering. Untuk bubuk kapur atau soda abu (soda ash) biasanya dipakai cara pembubuhan kering tetapi bisa juga memakai cara basah yaitu dengan melarutkan dalam air dengan konsentrasi 20-25\%.

5) Sedimentasi

Berdasarkan pengamatan yang telah dilakukan, didapatkan hasil bahwa unit sedimentasi termasuk dalam kategori penilaian "Baik" karena pada unit ini aliran air laminar, kecepatan dan waktu pengadukan sesuai dengan prosedur. Terdapat kantong lumpur serta pipa penguras yang dilengkapi dengan backwash.

6) Filtrasi

Berdasarkan pengamatan yang telah dilakukan, didapatkan hasil bahwa unit filtrasi termasuk dalam kategori penilaian "Baik”. Headloss ditunjukkan dengan adanya kloging (mampet) sehingga bak filtrasi berisi air yang melebihi batas level tertentu akibat dari kecepatan penyaringan menurun maka dilakukan backwashing.

Pada unit ini menggunakan pasir silika dapat memberikan hasil yang lebih baik dan jernih. Pasir silika mempunyai kelebihan sebagai media filtrasi yang baik karena dapat menyerap lumpur, tanah, dan partikel lainnya.

7) Desinfeksi

Berdasarkan pengamatan yang telah dilakukan, didapatkan hasil bahwa unit desinfeksi termasuk dalam kategori penilaian "Baik”. Penggunaan desinfektan jenis gas khlor hasilnya menjadi lebih bagus dan lebih baik.

Gas khlor mempunyai beberapa kelebihan antara lain :

a) Gas khlor mempunyai kadar $99,5 \% \mathrm{Cl}_{2}$ yang dikemas dalam kontainer $100 \mathrm{~kg}$, sehingga tidak membutuhkan ruangan yang besar untuk penyimpanannya.

b) Penyimpanan yang lama tidak mempengaruhi kadar khlor.

c) Operasi khlorinasi dengan gas khlor membutuhkan tenaga kerja yang lebih sedikit.

d) Tidak akan mengalami gangguan penyumbatan karena injeksi dalam bentuk gas.

e) Efisiensi khlorinasi tinggi karena injeksi gas khlor secara tertutup dan langsung ke dalam air.

f) Dosering lebih mudah tanpa penyetelan setiap hari.

g) Tidak ada atau tanpa limbah (bersih).

8) Reservoir

Berdasarkan pengamatan yang telah dilakukan, didapatkan hasil bahwa unit reservoir termasuk dalam kategori penilaian "Baik” karena bangunan terletak di permukaan tanah yang tinggi, terdapat pipa penguras, lubang hawa, dan manhole yang dikunci dengan baik.

\section{e. Kualitas air minum}

Berdasarkan data yang diperoleh dari Laboratorium Kesehatan Daerah Kebumen bahwa hasil kualitas bakteriologis air PDAM Tirta Bumi Sentosa sudah memenuhi standar sesuai Permenkes RI No.492/Menkes/Per/IV/2010 yaitu 0 MPN/100 ml Gol. Coliform, sedangkan berdasarkan data yang diperoleh dari BBTKLPP Yogyakarta, hasil kualitas fisika dan kimia air PDAM Tirta Bumi Sentosa ada yang sudah memenuhi standar dan ada yang belum memenuhi standar.

Hasil pemeriksaan tanggal 31 Maret 2017 untuk parameter fisika pada sampel yang diambil di sambungan rumah Kantor PDAM/ IPA Pelanggan/ S. Luk Ulo diperoleh hasil kualitas warna sebesar 37 TCU maka hal tersebut melebihi kadar maksimal yang diperbolehkan yaitu 15 TCU dan hasil kualitas kekeruhan sebesar 7 NTU sehingga melebihi kadar maksimal yaitu 5 NTU. Pada sampel yang diambil di gabungan Karangsari/ MA Kaliwinong/ Buayan diperoleh hasil kualitas warna sebesar 25 TCU maka hal tersebut melebihi kadar maksimal yaitu 15 TCU dan hasil kualitas kekeruhan sebesar 87 NTU sehingga sangat melebihi kadar maksimal yaitu 5 NTU. Pada sampel yang diambil di IPA Sempor/ Waduk Sempor/ Kebumen diperoleh hasil kualitas warna sebesar 20 TCU maka hal tersebut melebihi kadar maksimal yaitu 15 TCU.

Parameter kimia pada sampel yang diambil di sambungan rumah Bp. Suparmin Adikaryo/ IPA Buayan/ Goa Barat dan sambungan rumah Bp. Sakirin/ Karanganyar/ IPA Waduk Sempor diperoleh hasil kualitas pH air sebesar 6,4 maka hal tersebut kurang dari kadar yang diperbolehkan yaitu antara 6,5 - 8,5.

Berdasarkan pemeriksaan sisa khlor yang dilaksanakan tanggal 15 Mei 2017 pada titik klorinasi, air kran konsumen terdekat, pertengahan dan terjauh dari titik klorinasi jaringan distribusi PDAM Tirta Bumi Sentosa diperoleh hasil bahwa pada 28 sampel yang diambil terdapat 5 sampel yang sisa khlornya adalah 0 mg/liter, sedangkan menurut Permenkes RI No.492/Menkes/Per/IV/2010 kadar yang diperbolehkan yaitu antara 0,2-0,5 mg/liter, sehingga dapat dikatakan jika pada salah satu unit IKK maupun sambungan rumah yang dijadikan sampel tersebut tidak memiliki sisa khlor. 5 sampel diantaranya yang tidak memiliki sisa khlor yaitu SR Sruweng, SR Karanggedang Sruweng, SR Pasar Karanganyar, IKK Karanganyar dan SR PKM Kuwarasan.

Faktor yang mempengaruhi efisiensi desinfeksi antara lain : jumlah dan jenis khlorin yang digunakan, waktu kontak, jumlah mikroorganisme, $\mathrm{pH}$, dan adanya senyawa lain dalam air. Hal tersebut dapat diatasi dengan memperhatikan kebutuhan khlorin untuk air 
yang relatif jernih dan pada air yang mengandung suspensi padatan yang tidak terlalu tinggi biasanya kebutuhan relatif kecil. Khlorin akan bereaksi dengan berbagai jenis komponen yang ada pada air dan komponen-komponen tersebut akan berkompetisi dalam penggunaan khlorin sebagai bahan desinfeksi, sehingga pada air yang relatif lebih kotor sebagian besar akan bereaksi dengan komponen yang ada dan hanya sebagian kecil saja yang bertindak sebagai desinfeksi.

Adanya sisa khlor dimaksudkan agar mampu digunakan sebagai desinfektan cadangan ketika terjadi kontaminasi susulan. Sebagai contoh ketika pipa air mengalami kebocoran dan terkontaminasi bakteri, maka sisa khlor tersebut yang menjadi desinfektan. Berdasarkan Permenkes RI No. 32 Tahun 2017 tentang Standar Baku Mutu Kesehatan Lingkungan dan Persyaratan Kesehatan Air untuk Keperluan Higiene Sanitasi, Kolam Renang, Solus Per Aqua, dan Pemandian Umum bahwa air yang ada di PDAM Tirta Bumi Sentosa masih layak untuk didistribusikan karena terdapat banyak parameter lainnya yang memenuhi syarat kualitas air minum, termasuk parameter bakteriologis yang secara keseluruhan memenuhi syarat kualitas air minum.

\section{f. Kuantitas air minum}

Menurut Nusa Idaman Said (2008, h.36) persyaratan kuantitas dalam penyediaan air minum adalah ditinjau dari banyaknya air baku yang tersedia. Artinya air baku tersebut dapat digunakan untuk memenuhi kebutuhan sesuai dengan kebutuhan daerah dan jumlah penduduk yang akan dilayani. Banyaknya air baku yang tersedia di PDAM Tirta Bumi Sentosa mampu mencukupi dan memenuhi untuk kebutuhan penyediaan air minum di wilayah Kabupaten Kebumen sehingga semua penduduk terlayani dengan baik.

Persyaratan kuantitas juga dapat ditinjau dari standar debit air bersih yang dialirkan ke konsumen sesuai dengan jumlah kebutuhan air bersih. Kebutuhan air bersih masyarakat bervariasi, tergantung pada letak geografis, kebudayaan, tingkat ekonomi, dan skala perkotaan tempat tinggalnya. Dengan kapasitas produksi 322,50 liter/detik dan mampu memproduksi air per hari sebesar 18.949,54 $\mathrm{m}^{3}$ atau 18.949 .540 liter dengan jumlah pelanggan 146.464 jiwa.

Menurut Permendagri No. 23 Tahun 2006 tentang Pedoman Teknis dan Tata Cara Peraturan Tarif Air Minum pada PDAM bahwa untuk kategori desa setiap orangnya membutuhkan 60 liter/hari maka air yang digunakan sebesar 8.787.840 liter/orang/hari, sedangkan untuk kategori kota setiap orangnya membutuhkan 100 liter/orang/hari maka air yang digunakan sebesar 14.646.400 liter/orang/hari, dengan demikian artinya memenuhi syarat kuantitas air.

\section{Kesimpulan}

Proses pengolahan air minum yang dilaksanakan di PDAM Tirta Bumi Sentosa yaitu intake, transmisi air baku, prasedimentasi, koagulasi, flokulasi, sedimentasi, filtrasi, desinfeksi dan reservoir.

Hasil penilaian unit operasi pengolahan air minum yang termasuk dalam kategori penilaian "Baik" yang memenuhi standar sesuai dengan prosedur, antara lain: prasedimentasi, sedimentasi, filtrasi, desinfeksi, dan reservoir.

Hasil pemeriksaan kualitas air minum pada tanggal 15 Mei 2017 yang dilakukan oleh Laboratorium Kesehatan Daerah Kebumen bahwa parameter bakteriologis sudah memenuhi standar sesuai dengan Permenkes RI No.492/Menkes/Per/IV/2010 yaitu 0 MPN/100 ml Gol. Coliform, dan hasil pemeriksaan parameter fisika dan kimia tanggal 31 Maret 2017 yang dilakukan oleh BBTKLPP Yogyakarta menunjukkan bahwa parameter ada yang sudah memenuhi standar dan ada yang belum memenuhi standar. Parameter fisika yang belum memenuhi standar antara lain : warna dan kekeruhan, sedangkan parameter kimia yang belum memenuhi standar yaitu $\mathrm{pH}$ air.

Kuantitas air minum yang dihasilkan dengan kapasitas produksi 322,50 liter/detik yang mampu memproduksi air per hari sebesar 18.949,54 $\mathrm{m}^{3}$ atau 18.949.540 liter dengan jumlah pelanggan 146.464 jiwa. Jika untuk kategori desa setiap orangnya membutuhkan 60 liter/hari maka air yang digunakan sebesar 8.787.840 liter/orang/hari, sedangkan untuk kategori kota setiap orangnya membutuhkan 100 liter/orang/hari maka air yang digunakan sebesar 14.646.400 liter/orang/hari, dengan demikian artinya memenuhi syarat kuantitas air.

Wilayah pendistribusian dari PDAM Tirta Bumi Sentosa dibagi menjadi 7 daerah pelayanan yang meliputi 16 kecamatan, antara lain : Kecamatan Kebumen, Pejagoan, Alian, Ayah, Rowokele, Prembun, Kutowinangun, Buayan, Kuwarasan, Karanganyar, Sruweng, Karanggayam, Gombong, Sempor, Adimulyo dan Buayan.

\section{Ucapan Terimakasih}

Terimakasih disampaikan kepada karyawan dan karyawati PDAM Kabupaten Kebumen yang telah banyak memberikan ilmu dan masukannya, Bapak Hari Rudijanto IW, ST., M.Kes. selaku dosen pembimbing Karya Tulis Ilmiah, sahabat-sahabatku dan teman-teman satu angkatan yang sudah memberikan semangat, bantuan dan masukkan yang bermanfaat.

\section{Daftar Pustaka}

Agustina, Dian Vita, 2007, Studi Kasus Perumnas Banyumanik Kelurahan Srondol Wetan, http://eprints.undip.ac.id/15472/1/DianVitaAgust ina.pdf, diakses pada tanggal 7/11/2016, pukul 14.12 . 
Amalia, Riezka, 2002, Studi Pengolahan Air Bersih di PDAM Ibukota Kecamatan Purwojati Kabupaten Banyumas Tahun 2002, KTI, Jurusan Kesehatan Lingkungan.

Asmadi, dkk, 2011, Teknologi Pengolahan Air Minum, Yogyakarta : Gosyen Publishing.

Hidayat, Aziz Alimul, 2007, Metode Penelitian Kebidanan Teknik Analisis Data, Jakarta : Salemba Medika.

Hudiantari, Swari, 2009, Tinjauan Pengelolaan Air Minum di PDAM Kabupaten Pemalang Tahun 2009, KTI, Jurusan Kesehatan Lingkungan.

Indonesia, Kementerian Dalam Negeri, 2006, Peraturan Menteri Dalam Negeri No. 23 Tahun 2006 Tentang Pedoman Teknis dan Tata Cara Peraturan Tarif Air Minum pada PDAM, Jakarta : Kementerian Dalam Negeri RI.

_ Kementerian Kesehatan, 1990, Peraturan Menteri Kesehatan RI No. 416/Menkes/Per/IX/1990 Tentang Syarat-Syarat dan Pengawasan Kualitas Air, Jakarta : Kementerian Kesehatan RI.

, Kementerian Kesehatan, 2010, Peraturan
Menteri Kesehatan RI $\begin{array}{r}\text { No. } \\ \text { 492/MENKES/PER/IV/2010 }\end{array}$
, Kementerian Kesehatan, 2017, Peraturan Menteri Kesehatan RI No. 32 Tahun 2017 Tentang Standar Baku Mutu Kesehatan Lingkungan dan Persyaratan Kesehatan Air untuk Keperluan Higiene Sanitasi, Kolam Renang, Solus Per Aqua, dan Pemandian Umum, Jakarta : Kementerian Kesehatan RI.

, Pemerintah, 2004, Undang-Undang No. 7 Tahun 2004 Tentang Sumber Daya Air, Jakarta : Pemerintah RI.
Pemerintah, 2009, Undang-Undang RI No. 36 Tahun 2009 Tentang Kesehatan, Jakarta : Pemerintah RI.

— Pemerintah, 2014, Peraturan Pemerintah No. 66 Tahun 2014 Tentang Kesehatan Lingkungan, Jakarta : Pemerintah RI.

Juju, 2012, Unit-Unit Instalasi Pengolahan Air Minum, https://jujubandung.wordpress.com/2012/05/02/u nit-unit-instalasi-pengolahan-air-minum, diakses pada tanggal 24/1/2017, pukul 14.19.

Lestari, Bensu Jumiati, 2012, Karya Tulis Ilmiah, http://jumiatibensu.blogspot.co.id/2012/03/karyatulis-ilmiah.html, diakses pada tanggal 21/12/2016, pukul 09.28.

Munif, 2015, Prosedur dan Tahap Pengolahan Air, http://helpingpeopleideas.com/publichealth/prose s-pengolahan-air, diakses pada tanggal 24/1/2017, pukul 14.05.

Said, Nusa Idaman, 2002, Kualitas Air Minum dan Dampaknya Terhadap Kesehatan, Jakarta : Pusat Pengkajian dan Penerapan Teknologi Lingkungan. , 2008, Teknologi Pengolahan Air Minum “Teori dan Pengalaman Praktis”, Jakarta : Pusat Teknologi Lingkungan.

Saud, Gokul, 2015, Water Treatment, http://www.slideshare.net/gokulsaud/watertreatment-51942731, diakses pada tanggal 24/1/2017, pukul 14.31.

Suparmin, 2011, Teori dan Praktik Pengolahan Air Minum, Banyumas : Yayasan Sanitarian Banyumas (YASAMAS).

Sutrisno, Totok, 2006, Teknologi Penyediaan Air Bersih, Jakarta : Rineka Cipta.

, Totok, 2010, Teknologi Penyediaan Air Bersih, Jakarta : Rineka Cipta. 